\title{
発達加速現象の研究・その 23
}

-2008 年 2 月における平均初潮年齢の動向一

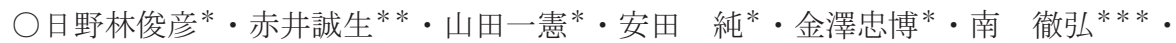

( *大阪大学大学院人間科学研究科、**大阪大学・大学教育実践センター、***大阪成蹊短期大学) キーワード:発達加速現象、初潮、思春期

\section{The secular trends of menarcheal age among Japanese schoolgirls}

(Hinobayashi Toshihiko*,Akai Seiki*, Yasuda Jun*, Yamada Kazunori*, Kanazwa Tadahiro*, MINAMI Tetsuhiro $* *$ ) ( $*$ Osaka University、 $* *$ Osaka Seikei College)

Keywords : secular trend, menarche, puberty

\section{I. 目的}

大阪大学における発達加速現象の研究グループは昭和 36 年以来、定期的に 11 回の全国規模の初潮調査を実施し、累 計 302 万人にのぼる初潮に関する個人資料を収集し、性成 熟に関する発達加速現象の研究を実施してきた。発達加速現 象は、欧米では1960 年から停止傾向が指摘され、日本で も1980 年代には停止傾向が見られた。しかし、初潮年齢 に関しては1990 年代にはいり新たな低年齢化傾向が見ら れ始め、近年、再停止状態にある。本研究の目的は 2008 年 2 月における日本の女子 - 児童生徒の初潮・初経の現状を 分析することである。

\section{II. 方法}

1. 調查対象者: 全国学校総覧より、4 7 都道府県から層化 二段抽出法により学校別に無為抽出された小学校 3,0 30 校、中学校 2,820 校、計 5,850 校に在籍する小学校 4 , 5,6 年、中学校 $1,2,3$ 年の女子。

2. 調查内容: 無記名で、生年月、初潮の有無、有りの場合 はその時期(学年と月)、および附加質問から構成されていた。 3 . 調查時期 : 平成 20 年 $(2008)$ 年 2 月に郵送で調査 票を送付、2月中に全国一斉に実施した。

4. 回収率・回答者(協力者)数: 今回の調査では、小学校 5 05 校 (回収率 $16.7 \%$ )、中学校 568 校（回収率 20 . $1 \%$ ）、全体としては 1,0 73 校（18．3\%）から回収さ れた。小・中学校とも、全国 47 都道府県のから回収されて いる。のべ回答者は 42 、0 24 人であったが、初潮に関す る有効回答者はの心゙、41，798人（99.5\%）であった。 これは、母集団（平成 20 年 5 月における全国の小 4 から中 3 の女子在籍者 $3 、 514 、 650$ 人）の 1 . $2 \%$ に相当す る。調査環境の悪化が続き、回収率が前回（2２．０％）か らさらに3．7\%低下している。しかしながら、全国的な傾 向を推定するのに十分な回収率と人数と考えられる。なお、 本調查 12 回の協力者の累計は $3,061,835$ 人となった。

\section{III. 結果}

1. 2008 年における全国平均初潮年齢

全国集計の結果、各学年別既潮率は以下のようであった。

（）は前回２００５年の既潮率である。

$$
\begin{aligned}
& \text { 小学校 } 4 \text { 年生： } 6.7 \%(6.8 \%) \\
& 5 \text { 年生： } 25.4 \%(24.8 \%) \\
& 6 \text { 年生 : } 58.3 \%(57.4 \%) \\
& \text { 中学校 } 1 \text { 年生 : } 83.4 \%(82.4 \%) \\
& 2 \text { 年生： } 95.2 \%(95.0 \%) \\
& 3 \text { 年生 : } 98.8 \%(98.5 \%)
\end{aligned}
$$

全学年 $1 \%$ 以下の変動であった。これら学年別の既潮率 (status quo method) からプロビット法(年齢の対数变換無 し、プロビットモデル)により推定した平均初潮年齢（初潮の 有り無しのみで計算する $50 \%$ 推定年齢、中央值)、は 12 . 189 歳（1 2 歳 2.3 力月）（標準誤差（95\%）：12 歳
0. 6 力月 12 歳 3.9 力月、標準偏差 1 歳 3.4 力月) で、前回より０．３力月早くなった。微弱な変動はあるもの の低年齢化は停止状態と考えられる。上記プロビット法によ る各既潮率到達推定年齢は以下のようであった。

既潮率 $01 \%$ ：9.201歳（9歳 2.4 力月） 既潮率 $05 \%$ ： 10 . 076 歳 ( 10 歳 0 . 9 力月) 既潮率 $10 \%$ : 1 0. 543 歳 ( 10 歳 6 . 5 力月) 既潮率 $20 \%$ : 1 1. 108 歳 (1 1 歳 1 . 3 力月) 既潮率 $30 \%$ ：1 1.5 515 歳（1 1 歳 6.2 力月） 既潮率 $40 \%$ : 11 . 864 歳（1 1 歳 10.4 力月） 既潮率 $50 \%$ : 12 . 189 歳 (12 歳 2. 3 力月) 既潮率 $60 \%$ : 12 . 515 歳（1 2 歳 6.2 力月） 既潮率 $70 \%$ : 12 . 863 歳 ( 12 歳 10 . 4 力月) 既潮率 $80 \%$ : 13 . 27 歳 (1 3 歳 3 . 2 力月) 既潮率 $90 \%$ : 13 . 835 歳 (1 3 歳 10 . 0 力月) 既潮率 $95 \%$ : 1 4. 302 歳（14 歳 3.6 力月） 既潮率 $99 \%$ : 1 5. 178 歳（15 歳 2. 1 力月）

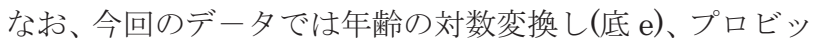
トモデルを用いた計算のほうが、相対的にあてはめがよい。 その場合 12.129 歳、標準偏差 1 歳 0.6 力となる。

既潮率を満月齢別にみると $50 \%$ を超えるのは 144 力月 (4 4.0\%)から 145 力月(52.8\%)であり、1 2 歳 0 カ 月から 1 カ月の間になる。前回より 1 カ月前傾している。 2. 全国平均初潮年齢の推移

本研究における日本の女子児童 - 生徒の平均初潮年齢（標準 偏差）の推移は以下のようであった。
1961 年：13 歳 2. 6 力月（1歳 2.2 力月)
1964 年: 13 歳 1 . 1 力月 ( 1 歳 1.6 力月)
1967 年：12 歳 10.4 力月（1歳 1.7 力月)
1972 年: 12 歳 7 . 6 力月 ( 1 歳 1.6 力月)
1977 年: 12 歳 6 . 0 力月 ( 1 歳 1.6 力月)
1982 年: 12 歳 6.5 力月 ( 1 歳 1 . 0 力月)
1987 年: 12 歳 5.9 力月 ( 1 歳 1.1 力月)
1992 年: 12 歳 3.7 力月 ( 1 歳 1.1 力月)
1997 年: 12 歳 2 . 0 力月 ( 1 歳 1.2 力月)
2002 年： 12 歳 2 . 0 力月 ( 1 歳 2.9 力月)
2005 年: 12 歳 2 . 6 力月 ( 1 歳 3.6 力月)
2008 年: 12 歳 2.3 力月 ( 1 歳 3.4 力月)

\section{IV. 考察}

1992 年の調査で、それまで 12 歳 6 力月前後で停滞傾 向にあった日本の女子初潮年齢は、新たな低年齢化傾向を示 した。1 997 年の調査でも、さらに低年齢化傾向が進行し ていることが確認された。この新しい低年齢化傾向は、身長 の伸びをほとんど伴わないところが、従来の発達加速現象と は異なるものであった。今回の調査より、日本女性の平均初 潮年齢は 12 歳 2.0 力月前後で、第二次世界大戦後二度目 の停滞傾向が持続していると考えられる。 